\title{
PENGARUH PENGELOLAAN ALOKASI DANA DESA TERHADAP PENINGKATKAN KESEJAHTERAAN MASYARAKAT
}

\author{
Mutia Sumarni \\ Fakultas Ekonomi dan Bisnis Islam IAIN Langsa \\ Email: muetiasumarni@gmail.com
}

\begin{abstract}
This study aims to examine the effect of village fund management on improving the welfare of the community. This research uses quantitative research methods. The population in this study was the population of 2077 people, with the method of probability sampling with simple random sampling while the sample size was obtained from calculations using the Slovin formula with an error rate of 5\% from 95 people. Sources of data in this study are primary data in the form of questionnaires. The data analysis technique used is simple linear regression analysis. Measurement of the questionnaire answered by respondents using a Likert scale using the Statistical Package for Social Sciences (SPSS). The results of this study indicate that the management of village funds to improve welfare has a positive effect. While the adjusted $R_{2}$ value is 0.46 which shows the effect of the independent variable on the dependent variable that can be explained by the equation model is $46.0 \%$.
\end{abstract}

Keywords: Village fund management and welfare level

\begin{abstract}
Abstrak
Penelitian ini bertujuan untuk menguji pengaruh pengelolaan dana desa terhadap peningkatan kesejahteraan masayarakat. Penelitian ini menggunakan metode penelitian kuantitatif. Populasi dalam penelitian ini adalah masyarakat payabujuk beramo langsa yang berjumlah 2077 orang, sampel dalam penelitian ini menggunakan teknik probability sampling dengan jenis pengambilan sampel simple random sampling sedangkan ukuran sampel diperoleh dari perhitungan menggunakan rumus Slovin dengan Tingkat kesalahan $5 \%$ dari 95 orang. Sumber data dalam penelitian ini adalah data primer dalam bentuk kuesioner. Teknik analisis data yang digunakan adalah analisis regresi linier sederhana. Pengukuran kuesioner yang dijawab oleh responden menggunakan skala likert menggunakan Paket Statistik untuk Ilmu Sosial (SPSS). Hasil penelitian ini menunjukkan bahwa pengelolaan dana desa terhadap peningkatan kesejahteraan memiliki pengaruh positif. Sedangkan nilai adjusted $\mathrm{R} 2$ adalah 0,46 yang menunjukkan pengaruh variabel independen terhadap variabel dependen yang dapat dijelaskan oleh model persamaan adalah $46,0 \%$.
\end{abstract}

Kata kunci: Pengelolaan dana desa dan tingkat kesejahteraan 


\section{PENDAHULUAN}

Desa merupakan sebuah komunitas kecil yang terikat pada lokalitas tertentu baik sebagai tempat tinggal dan juga tempat pemenuhan kebutuhan hidup masyarakat desa yang bergantung kepada pertanian (Rahardjo, 2010 : 28). Pengertian dari masyarakat itu merupakan sekelompok manusia yang saling berinteraksi sehingga dalam masyarakat tersebut akan terdapat kesepakatan-kesepakatan yang telah ditentukan agar ditaati dan dilaksanakan oleh setiap anggota masyarakat. Kesepakatan-kesepakatan yang sudah ada dalam masyarakat kemudian menjadi pedoman pada setiap warganya, sehingga dapat membedakan antara masyarakat yang satu dengan yang lain (Soerjono Soekanto, $2006: 22$ ).

Berdasarkan Peraturan Pemerintah Nomor 72 Tahun 2005 tentang Desa pasal 68 ayat 1 poin c, menyebutkan bahwa bagian dari dana perimbangan pusat dan daerah yang diterima oleh kabupaten/kota untuk desa, paling sedikit 10\% secara proposional pembagiannya untuk setiap desa, dana ini dalam bentuk Alokasi dana Desa atau sering disebut sebagai ADD. Alokasi Dana Desa (ADD) merupakan dana yang dialokasikan oleh Pemerintah Kabupaten untuk desa, yang bersumber dari bagian dana perimbangan keuangan pusat dan daerah yang diterima oleh Kabupaten. Alokasi Dana Desa merupakan dana yang cukup signifikan bagi Desa untuk menunjang program-program Desa. Pengelolaan keuangan baik dari anggaran sampai realisasi harus melibatkan tokoh-tokoh masyarakat dan aparat Pemerintah Daerah. Kendala-kendala yang dihadapi oleh Pemerintah Daerah baik Pemerintah desa dan Pemerintah Kecamatan adalah kurangnya pengendalian terhadap pengelolaan dana yang berasal dari Alokasi Dana Desa.

Alokasi Dana Desa (ADD) juga dimaksudkan untuk membiayai sebagian program pemerintahan desa dalam melaksanakan kegiatan pemberdayaan dan kelembagaan desa, pemberian tunjangan aparatur pemerintah desa serta pemberian dana pembangunan infrastruktur pedesaan. Untuk melaksanakan kewenangan tersebut, pemerintah desa memiliki sumber-sumber penerimaan yang digunakan untuk membiayai kegiatan yang dilakukannya. Salah satu hal yang paling penting untuk diperhatikan dalam mendukung proses pelaksanaan pembangunan disetiap desa adalah adanya kepastian keuangan untuk pembiayaan. Salah satunya dengan penerimaan Alokasi Dana Desa (ADD). Penggunaan Alokasi Dana Desa (ADD) juga harus memberikan manfaat yang sebesar-besarnya dengan memprioritaskan kegiatan pembangunan dan pemberdayaan masyarakat desa yang bersifat mendesak untuk dilaksanakan, serta lebih dibutuhkan dan berhubungan langsung dengan kepentingan sebagian besar masyarakat desa.

Alokasi dana desa di Gampong Paya Bujok Beuramoe Kecamatan Langsa Barat 
digunakan untuk pemberdayaan dan pembangunan infrastruktur seperti pembuatan pagar kantor desa, rehap gedung kantor desa, pelatihan, gaji perangkat desa dan kepala desa, tunjangan BPD pembuatan batas dusun, dan pembelian perlengkapan kantor desa. Sehingga dengan adanya pembangunan tersebut akan menambah pendapatan bagi masyarakat Gampong Paya Bujok Beuramoe Kecamatan Langsa Barat. Namun tingkat kesadaran masyarakat untuk melakukan suatu perubahan yang didanai oleh alokasi dana desa masih sangat rendah. Disebabkan karena tingkat pendidikan masyarakat masih sangat rendah. Hal ini disebabkan karena minimnya sumber daya yang ada dan kontrol dari Pemerintah dan Masyarakat yang kurang. Oleh karena itu perlu diketahui sejauh mana pengelolaan Dana Desa dalam program Desa sehingga tujuan Pemerintah mengalokasikan Dana Pemerintah Pusat dan Daerah bisa membantu program Desa dan tujuan Pemerintah terwujud demi kesejahteraan masyarakat. Oleh karena itu penulis melaksanakan penelitian dengan judul "Analisis Pengelolaan Alokasi Dana Desa Desa Untuk Meningkatkan Kesejahteraan Masyarakat Gp Paya Bujok Beuramoe Kecamatan Langsa Barat”.

\section{LANDASAN TEORITIS}

\section{Pengelolaan Alokasi Dana Desa (ADD)}

Menurut peraturan mentri dalam negeri Republik Indonesia Nomor 113 tahun 2014 tentang pengelolaan keuangan desa, menyatakan bahwa pengelolaan keuangan desa adalah keseluruhan kegiatan yang meliputi perencanaan, pelaksanaan, penatausahaan, pelaporan, dan pertanggungjawaban keuangan desa.

Siklus pengelolaan berdasarkan Undang-Undang Desa meliputi: 1) Penyiapan Rencana; 2) Musrenbang desa yang melibatkan pemerintah desa, BPD, dan kelompok masyarakat yang diawali dengan tingkat dusun hingga tingkat desa; 3) Penetapan Rencana, rencana disini merupakan pedoman APB Desa; 4) Penetapan APB Desa; 5) Pelaksanaan Pembangunan, melibatkan seluruh masyarakat secara swakelola; 6) Pertanggungjawaban, pemerintah desa wajib menyampaikan laporan dalam musyawarah pembangunan desa; 7) Pemanfaatan dan Pemeliharaan (UU No. 6 Tahun 2014). Pengelolaan Dana Desa meliputi tiga kegiatan penting yaitu Perencanaan, Pelaksanaan, dan Pertanggungjawaban.

\section{Perencanaan}

Perencanaan merupakan tahap awal dalam pengelolaan ADD. Kegiatan perencanaan ini dilakukan untuk menyusun kegiatan pelaksanaan ADD. Pertama, tiap dusun akan mengadakan Musyawarah Dusun (Musdus) untuk menampung usulan-usulan masyarakat mengenai program kerja apa saja yang akan dilakukan untuk tahun yang 
berkenaan (Permendagri No. 113 tahun 2014).

\section{Pelaksanaan}

Dalam pelaksanaan kegiatan-kegiatan yang pembiayaanya bersumber dari ADD sepenuhnya dilaksanakan oleh Tim Pelaksana Desa (Pemerintah Desa). Untuk mendukung keterbukaan dan penyampaian informasi secara jelas kepada masyarakat, maka pada setiap pelaksanaan kegiatan fisik ADD wajib dilengkapi dengan papan informasi kegiatan yang dipasang di lokasi kegiatan. Papan tersebut sekurang-kurangnya memuat nama kegiatan, volume kegiatan, besaran anggaran dari ADD maupun swadaya masyarakat, dan waktu pelaksanaan kegiatan seperti yang telah disepakati dalam Musrenbangdes (Diansari, 2015).

\section{Pertanggungjawaban}

Dalam melaksanakan tugas, wewenang, hak dan kewajibannya dalam pengelolaan keuangan desa, Kepala Desa memiliki kewajiban untuk menyampaikan laporan. Laporan tersebut bersifat periodik semesteran dan tahunan, yang disampaikan ke Bupati/Walikota dan ada juga yang disampaikan ke BPD. Rincian laporan sebagai berikut (Permendagri No. 113 Tahun 2014):

Laporan kepada Bupati/Walikota (melalui Camat):

a. Laporan Semesteran Realisasi Pelaksanaan APB Desa.

Laporan Semesteran ini terdiri dari Laporan Semester Pertama yang diserahkan paling lambat pada akhir bulan Juli tahun berjalan; dan Laporan Akhir yang diserahkan paling lambat pada akhir bulan Januari (DJBPD, 2016).

b. Laporan Pertanggungjawaban Realisasi Pelaksanaan APB Desa kepada Bupati/ Walikota setiap akhir tahun

Laporan ini diserahkan kepada Bupati/Walikota melalui Camat, yang terdiri dari Pendapatan, Belanja, dan Pembiayaan yang telah ditetapkan dengan peraturan desa. Setelah pemerintah desa dan BPD telah sepakat Laporan Pertanggungjawaban Realisasi Pelaksanaan APB Desa dalam bentuk Peraturan Desa (Perdes), maka Perdes ini disampaikan kepada Bupati/Walikota sebagai bagian tidak terpisahkan dari Laporan Penyelenggaraan Pemerintahan Desa. Laporan Pertanggungjawaban Realisasi Pelaksanaan APB Desa sebagaimana tercantum dalam pasal 41 Permendagri No. 113 Tahun 2014, disampaikan paling lambat satu bulan setelah tahun anggaran berkenaan (DJBPD, 2016) 
c. Laporan Realisasi Penggunaan Dana Desa.

Laporan Realisasi Penggunaan Dana Desa disampaikan kepada Bupati/Walikota setiap semester. Penyampaian laporan realisasi penggunaan Dana Desa dilakukan untuk Semester I paling lambat minggu keempat bulan Juli TA berjalan dan untuk Semester II paling lambat minggu keempat bulan Januari TA berikutnya (BPKP, 2015).

\section{Kesejahteraan Masyarakat}

Menurut Soetomo (2014:47) kesejahteraan merupakan suatu kondisi yang mengandung unsur atau komponen ketertiban-keamanan, keadilan, ketentraman, kemakmuran dan kehidupan yang tertata mengandung makna yang luas bukan hanya terciptanya ketertiban dan keamanan melainkan juga keadilan dalam berbagai dimensi. Kondisi tentram lebih menggambarkan dimensi sosiologi dan psikologi dalam kehidupan bermasyarakat. Suatu kehidupan yang merasakan suasana nyaman, terlindungi, bebas dari rasa takut termaksud menghadapi hari esok. Dengan demikian kondisi sejahtera yang diidamkan bukan hanya gambaran kehidupan yang terpenuhi fisik, material, melainkan juga spiritual, bukan hanya pemenuhan kebutuhan jasmaniah melainkan juga rohaniah.

\section{Indikator Kesejahteraan Masyarakat}

Indikator kesejahteraan menurut Soetomo (2014:48) mengandung tiga komponen yaitu:

1). Keadilan sosial mengandung sejumlah indikator yaitu: pendidikan, kesehatan, akses pada listrik dan air, penduduk miskin

2). Keadilan ekonomi mengandung sejumlah indikator yaitu: pendapatan, kepemilikan rumah, tingkat pengeluaran.

3). Keadilan demokrasi mengandung sejumlah indikator yaitu: rasa aman dan akses informasi

\section{Tujuan Kesejahteraan}

Menurut Fahrudin (2012:10) mempunyai tujuan yaitu:

a). Untuk mencapai kehidupan yang sejahtera dalam arti tercapainya standar kehidupan pokok.

b). Untuk mencapai penyesuaian diri yang baik khusunya dengan masyarakat di lingkungannya, misalnya dengan menggali sumber-sumber meningkatkan dan mengembangkan taraf hidup yang memuaskan 


\section{Langkah-Langkah Mencapai Kesejahteraan}

Untuk mencapai kesejahteraan tidaklah gampang, dibutuhkan program program yang bagus dalam menjalankannya. Dan salah satunya adalah program ADD. Program ini adalah program yang dirancang oleh pemerintah Indonesia untuk mempercepat penanggulangan kemiskinan secara terpadu dan berkelanjutan dan dititik beratkan pada pencapaian kesejahteraan dan kemandirian masyarakat miskin pedesaan. Berikut beberapa langkah yang ditempuh dalam mencapai hal tersebut antara lain:

a. Peningkatan kapasitas masyarakat dan kelembagaannya

b. Pelembagaan sistem pembangunan partisipasif

c. Pengefektifan fungsi dan peran pemerintah lokal

d. Peningkatan kualitas dan kuantitas prasarana dan sarana sosial dasar dan

e. ekonomi masyarakat

\section{METODE}

Penelitian ini menggunakan metode kuantitatif. Lokasi atau tempat penelitian ini adalah Gampong Paya Bujok Beuramoe Kecamatan Langsa Barat. Populasi pada penelitian ini adalah seluruh penduduk gampong paya bujok beramo sebanyak 2077 orang, Sedangkan sampel penelitian sebanyak 95 orang dari penduduk gampong paya bujok beramo. Pengambilan sampel dengan menggunakan metode simple random sampling yaitu pengambilan anggota sampel dari populasi dilakukan secara acak tanpa memperhatikan strata yang ada dalam populasi itu. Data-data yang diperlukan dalam penelitian ini, dikumpulkan melalui Metode Angket (Kuesioner).

Teknik analisis data dalam penelitian ini meliputi uji keabsahan data, terdiri dari uji validitas, uji reabilitas. Uji asumsi klasik, terdiri dari uji normalitas, uji multikolinearitas, uji heterokedastisitas dan uji hipotesis, analisis regesi linear sederhana, uji model $r^{2}$ (koefisien determinasi) dan uji t (uji parsial) (Juliandi dan Irfan, 2013: 128).

\section{HASIL DAN PEMBAHASAN}

Dalam rangka menjawab hipotesis yang telah diajukan maka dilakukan serangkaian pengujian dan analisis. Diantara uji dan analisis tersebut adalah uji asumsi klasik (multikolinearitas, normalitas, heterokedastisitas, autokorelasi) dan uji T. 


\section{Uji Validitas}

Uji validitas dilakukan dengan bantuan SPSS Versi 17 yang bertujuan untuk mengetahui bahwa setiap butir pertanyaan dan pernyataan yang diajukan kepada responden telah dinyatakan valid atau tidak. Teknik yang digunakan dalam penelitian ini adalah dengan teknik korelasi, yaitu dengan membandingkan hasil koefisien korelasi $r_{\text {hitung }} r_{\text {hitung }}$ dengan $r_{\text {tabel }} r_{\text {tabel }}$. Jika koefisien korelasi $r$ hitung lebih besar dari $r$ tabel maka butir-butir penelitian ini dikatakan valid. Dengan menggunakan $\mathrm{N}=95$ didapatkan $r$ tabel $=0,2876$. Dari hasil uji validitas diperoleh tabel sebagai berikut:

\begin{tabular}{lllll}
\hline Variabel & Item Pernyataan & Nilai Korelasi & Probabilitas & Keterangan \\
\hline \multirow{3}{*}{ Pengelolaan } & Pernyataan 1 & 0,692 (Positif) & $0,000<0,05$ & Valid \\
Dana Desa & Pernyataan 2 & 0,727 (Positif) & $0,000<0,05$ & Valid \\
(X) & Pernyataan 3 & 0,721 (Positif) & $0,000<0,05$ & Valid \\
& Pernyataan 4 & 0,739 (Positif) & $0,000<0,05$ & Valid \\
& Pernyataan 5 & 0,749 (Positif) & $0,000<0,05$ & Valid \\
& Pernyataan 6 & 0,539 (Positif) & $0,000<0,05$ & Valid \\
Kesejahteraan & Pernyataan 1 & 0,788 (Positif) & $0,000<0,05$ & Valid \\
(Y) & Pernyataan 2 & 0,656 (Positif) & $0,000<0,05$ & Valid \\
& Pernyataan 3 & 0,623 (Positif) & $0,000<0,05$ & Valid \\
& Pernyataan 4 & 0,687 (Positif) & $0,000<0,05$ & Valid \\
& Pernyataan 5 & 0,585 (Positif) & $0,000<0,05$ & Valid \\
& Pernyataan 6 & 0,673 (Positif) & $0,000<0,05$ & Valid \\
\hline
\end{tabular}

Sumber : Data Primer diolah dengan SPSS, 2019

\section{Uji Reliabilitas}

Suatu kuesioner dikatakan reliabel atau handal jika jawaban seseorang terhadap pertanyaan dan pernyataan adalah konsisten atau stabil dari waktu ke waktu. SPSS memberikan fasilitas untuk mengukur reliabilitas dengan uji statistik Cronbach Alpha (ả).(Imam Ghozali : 2005)

Reliabilitas sebenarnya adalah alat untuk mengukur suatu kuesioner yang merupakan indikator dari variabel atau konstruk.Suatu kuesioner dikatakan reliabel atau handal jika jawaban seseorang terhadap pernyataan adalah konsisten atau stabil dari waktu ke waktu.SPSS memberikan fasilitas untuk mengukur reliabilitas dengan uji statistik Cronbach Alpha.

Untuk mengetahui hasil uji reliabilitas, maka dilakukan dengan cara membandingkan antara nilai alpha ( $\alpha$ ) dengan nilai $r_{t a b_{e l}} r_{\text {tabel }}$. Jika nilai alpha ( $\alpha$ ) lebih besar dari $r_{\text {tabel }} r_{\text {tabel }}$, maka hasilnya adalah reliabel.

Menggunakan sampel untuk uji kuesioner sebanyak 95 orang responden dengan signifikansi $5 \%$, dari sini di dapat nilai $d f=n-2, d f=95-1=94(0,2876)$ 
Hasil Uji Reliabilitas

\begin{tabular}{cll}
\hline Variabel & Alpha $(\alpha)$ & Keterangan \\
\hline Pengelolaan Dana & 0,713 & Reliabel \\
$\begin{array}{l}\text { Desa }(\mathrm{X}) \\
\text { Kesejahteraan }(\mathrm{Y})\end{array}$ & 0,766 & Reliabel \\
\hline
\end{tabular}

Sumber : Data Primer diolah dengan SPSS, 2019

\section{Uji Asumsi Klasik}

\section{Uji Normalitas}

Uji normalitas digunakan untuk mengetahui apakah dalam model regresi variabel pengganggu atau residual memiliki distribusi normal. Uji normalitas dengan grafik normal P-P Plot akan membentuk satu garis lurus diagonal kemudian plotting data akan dibandingkan dengan garis diagonal. Jika distribusi normal maka garis yang menggambarkan data sesungguhnya akan mengikuti garis diagonal. Adapun grafik normal uji normalitas dapat dilihat pada gambar berikut :

\section{Normal P-P Plot of Regression Standardized Residual}

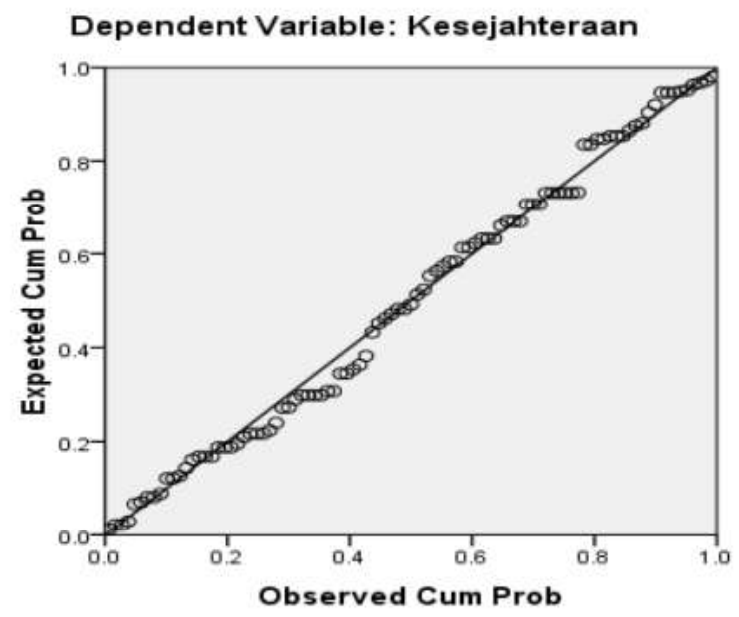

Sumber : Data diolah

\section{Uji Multikolinearitas}

Pengujian ini bertujuan untuk mengetahui apakah setiap variabel saling berhubungan secara linear atau tidak. Uji multikolinearitas dapat dilihat dari Variance Inflation Faktor (VIF) dan nilaitolerance. Kedua ukuran ini menunjukkan sikap variabel independen manakah yang dijelaskan variabel indeppenden lainnya.Multikolinearitas terjadi jika nilai tolerance $<0.10$ atau sama dengan VIF $>0.10$ tidak ada yang melebihi 
10, maka dapat dikatakan bahwa multikolinearitas yang terjadi tidak berbahaya (lolos uji multikolinearitas). Adapun hasil dari pengujiannya adalah sebagai berikut:

\section{Coefficients $^{\mathrm{a}}$}

\begin{tabular}{|c|c|c|c|c|c|c|c|c|}
\hline & \multirow[t]{2}{*}{ Model } & \multicolumn{2}{|c|}{$\begin{array}{l}\text { Unstandardized Coef- } \\
\text { ficients }\end{array}$} & \multirow{2}{*}{$\begin{array}{l}\text { Standardized } \\
\text { Coefficients } \\
\text { Beta }\end{array}$} & \multirow[t]{2}{*}{$\mathrm{t}$} & \multirow[t]{2}{*}{ Sig. } & \multicolumn{2}{|c|}{ Collinearity Statistics } \\
\hline & & $\mathrm{B}$ & Std. Error & & & & Tolerance & $\mathrm{VIF}$ \\
\hline \multirow[t]{3}{*}{1} & (Constant) & 9.031 & 1.519 & & 5.946 & .000 & & \\
\hline & Pengelolaan & .471 & .052 & 682 & 8.995 & .000 & 1.000 & 1.000 \\
\hline & Dana Desa & & & & & & & \\
\hline
\end{tabular}

a. Dependent Variable:

Kesejahteraan

Sumber: data diolah

Hasil uji multikolinearitas (uji VIF) Pada di atas menunjukkan bahwa nilai VIF kurang dari 10 dan tolerance lebih dari 0.1, yang berarti bahwa model regresi tidak mengandung multikolinearitas. Artinya tidak terjadi korelasi antar variabel independen. Model regresi yang baik seharusnya tidak terjadi korelasi diantara variabel independen.Jika variabel independen saling berkorelasi, maka variabel ini tidak ortogonal. Variabel ortogonal adalah variabel independen yang nilai korelasi antar sesama variabel independen sama dengan nol.

\section{Uji Heterokedastisitas}

Uji heterokedastisitas berfungsi untuk menguji terjadinya perbedaan variance dari nilai residual pada suatu periode pengamatan ke periode pengamatan yang lain.

Scatterplot

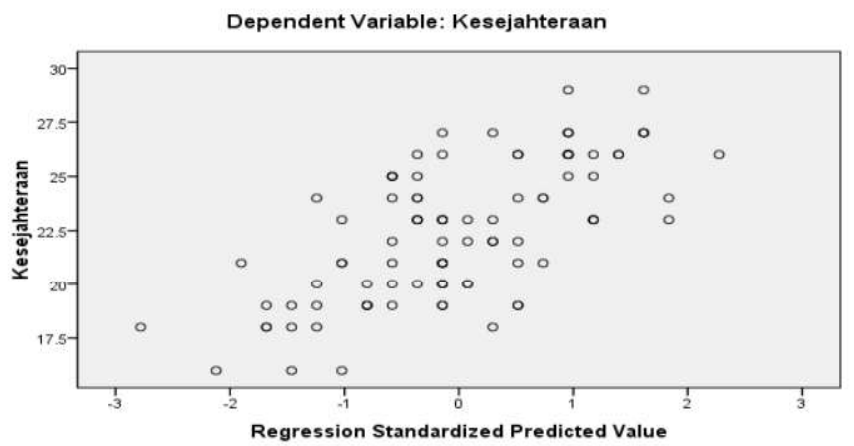

Berdasarkan gambar di atas terlihat titik-titik pada grafik plot menyebar atau tidak membentuk pola tertentu. Artinya tidak terjadi heteroskedastisitas pada model regresi yang digunakan.

\section{Uji Autokolerasi}

Uji autokorelasi bertujuan menguji apakah dalam model regresi terdapat korelasi antara kesalahan pengganggu pada periode t dengan kesalahan pengganggu 
pada periode t-1. Cara untuk mendeteksi ada atau tidaknya autokorelasi adalah dengan uji Durbin-Watson (DW-test). Hasil perhitungan uji Durbin-Watson yang ada akan dibandingkan dengan nilai tabel dari Durbin-Watson. Untuk penelitian ini, hasil uji autokorelasi adalah sebagai berikut :

Model Summary

\begin{tabular}{ccccc}
\hline Model & $\mathrm{R}$ & $\mathrm{R}$ Square & Adjusted R Square & Std. Error of the Estimate \\
\hline 1 & $.682^{\mathrm{a}}$ & .465 & .460 & 2.310 \\
\hline
\end{tabular}

a. Predictors: (Constant), Pengelolaan Dana Desa

b. Dependent Variable: Kesejahteraan

Selanjutnya nilai ini akan kita bandingkan dengan nilai tabel signifikansi 5\% dengan jumlah sampel $n=95$ dan jumlah variabel independen $1(k=1)=2,472$ maka diperoleh nilai du 1,6662. Nilai DW 2,471 lebih besar dari batas atas (du) yakni 1,6662. dan kurang dari (4-du) 4 - 1,6662 = 2,3338 sehingga dapat disimpulkan bahwa tidak terdapat autokorelasi.

\section{Analisis Regresi Sederhana}

Coefficientsa

\begin{tabular}{|c|c|c|c|c|c|c|c|c|}
\hline \multirow[b]{2}{*}{ Model } & & \multicolumn{2}{|c|}{$\begin{array}{l}\text { Unstandardized Coef- } \\
\text { ficients }\end{array}$} & \multirow{2}{*}{$\begin{array}{c}\begin{array}{c}\text { Standardized } \\
\text { Coefficients }\end{array} \\
\text { Beta } \\
\end{array}$} & \multirow[t]{2}{*}{$\mathrm{t}$} & \multirow[t]{2}{*}{ Sig. } & \multicolumn{2}{|c|}{ Collinearity Statistics } \\
\hline & & $\mathrm{B}$ & Std. Error & & & & Tolerance & VIF \\
\hline \multirow[t]{2}{*}{1} & (Constant) & 9.031 & 1.519 & & 5.946 & .000 & & \\
\hline & $\begin{array}{l}\text { Pengelolaan } \\
\text { Dana Desa }\end{array}$ & .471 & .052 & .682 & 8.995 & .000 & 1.000 & 1.000 \\
\hline
\end{tabular}

a. Dependent Variable:

Kesejahteraan

Berdasarkan output regresi linier sederhana dari tabel di atas, didapat model persamaan regresinya yang dirumuskan sebagai berikut:

$$
Y=9,031+0,471 X
$$

Dari persamaan regresi tersebut dapat diketahui bahwa:

1. Nilai konstanta (Y) atau kesejahteraan masyarakat menunjukkan angka sebesar 9,031 yang berarti bahwa bila tidak ada perubahan pengelolaan 
dana desa maka kesejahteraan bisa mencapai nilai sebesar 9,031. Hal ini menandakan adanya pengaruh variabel lain selain pengelolaan dana desa.

2. Koefesien regresi pengelolaan dana desa menunjukkan angka sebesar 0,471 . Hal ini berarti bahwa adanya perubahan positif antara perubahan pengelolaan dana desa terhadap kesejahteraan masyarakat. Setiap peningkatan pengelolaan dana desa sebesar $1 \%$, maka akan meningkatkan kesejahteraan masyarakat sebesar $1 \%$.

\section{Uji Hipotesis}

\section{Uji Parsial (Uji t)}

Pengujian hipotesis yang menyatakan ada pengaruh secara parsial pengelolaan dana desa terhadap kesejahteraan dapat dilihat dari hasil uji t. Uji t statistik menunjukkan seberapa jauh pengaruh satu variabel independen secara parsial dalam menerangkan variasi variabel dependen.

Coefficients $^{\mathrm{a}}$

\begin{tabular}{|c|c|c|c|c|c|c|c|c|}
\hline & \multirow{2}{*}{ Model } & \multicolumn{2}{|c|}{$\begin{array}{l}\text { Unstandardized } \\
\text { Coefficients }\end{array}$} & \multirow{2}{*}{$\frac{\begin{array}{c}\text { Standardized } \\
\text { Coefficients }\end{array}}{\text { Beta }}$} & \multirow[t]{2}{*}{$\mathrm{t}$} & \multirow[t]{2}{*}{ Sig. } & \multicolumn{2}{|c|}{ Collinearity Statistics } \\
\hline & & B & Std. Error & & & & Tolerance & VIF \\
\hline \multirow[b]{2}{*}{1} & (Constant) & 9.031 & 1.519 & & 5.946 & .000 & & \\
\hline & $\begin{array}{c}\text { Pengelolaan } \\
\text { Dana Desa }\end{array}$ & .471 & .052 & .682 & 8.995 & .000 & 1.000 & 1.000 \\
\hline
\end{tabular}

a. Dependent Variable:

Kesejahteraan

Sumber : data diolah

Berdasarkan hasil pengujian secara parsial pengaruh pengelolaan dana desa terhadap kesejahteraan masyarakat dengan menggunakan program SPSS diperoleh $\mathbf{t}_{\text {hitung }}$ sebesar 8.995 dengan $p$ value 0,000 . Berdasarkan ketentuannya jika $p$ value< dari 0,05 maka hipotesis alernatif ( $\mathrm{Ha}$ ) diterima, oleh karena $\mathrm{p}$ value $<$ 0,05 maka ini berarti variabel independen pengelolaan dana desa secara parsial berpengaruh positif signifikan terhadap variabel dependen kesejahteraan masyarakat.

\section{Uji Model R ${ }^{2}$}

Koefisien Determinasi $\left(\mathrm{R}^{2}\right)$ pada intinya mengukur seberapa jauh kemampuan model dalam menerangkan variasi variabel dependen. Koefisien determinasi dalam penelitian ini menggunakan nilai $R^{2}$. Hasil uji $R^{2} R^{2}$ dapat dilihat pada dibawah ini: 


\section{Model Summary ${ }^{\mathrm{b}}$}

\begin{tabular}{|l|r|r|r|r|}
\hline Model & \multicolumn{1}{|c|}{$\mathrm{R}$} & R Square & \multicolumn{1}{c|}{$\begin{array}{c}\text { Adjusted } \mathrm{R} \\
\text { Square }\end{array}$} & $\begin{array}{l}\text { Std. Error of the } \\
\text { Estimate }\end{array}$ \\
\hline 1 & $.682^{\mathrm{a}}$ & .465 & .460 & 2.310 \\
\hline
\end{tabular}

a. Predictors: (Constant), Pengelolaan Dana Desa

\section{b. Dependent Variable: Kesejahteraan}

Data di atas menunjukkan nilai Adjusted R-Square sebesar 0,460, hal ini berarti bahwa 46,0 \% nilai variasi kesejahteraan ditentukan oleh variabel dalam model penelitian, dan sisanya 54,0 dipengaruhi oleh variabel lain diluar model.

Berdasarkan hasil pengujian hipotesis menujukkan dana desa berpengaruh positif dan signifikan terhadap kesejahteraan masyarakat. Hasil penelitian ini menunjukkan dana desa memiliki hubungan yang positif dan signifikan terhadap kesejahteraan masyarakat. Hal ini berarti bahwa dana desa akan mempengaruhi kesejahteraan masyarakat. Berkenaan dengan dikucurkannya dana desa dan alokasi dana desa diharapkan proses pembangunan daerah secara keseluruhan akan dapat ditingkatkan dan secara bersama ketimpangan pembangunan antar wilayah akan pula dapat dikurangi. Pemerintah memiliki posisi yang sangat penting dalam menciptakan keadilan distribusi, karena menciptakan kesejahteraan di masyarakat merupakan kewajiban seluruh agen ekonomi. Disamping itu, pemerintah juga berperan sebagai penjamin terciptanya distribusi yang adil serta menjadi fasilitator pembangunan manusia dan menciptakan kesejahteraan masyarakat (Pitri, 2018).

Hasil penelitian ini didukung dengan penelitian yang dilakukan oleh Rusydi (2012) yang menyatakan kegiatan pengalokasian ADD cukup efektif untuk meningkatkan kesejahteraan masyarakat. Oleh kerana itu kegiatan pengawasan perlu dilakukan untuk memastikan agar tidak ada penyelewengan anggaran dan benarbenar diperuntukkan sebagaimana mestinya. Pengawasan adalah kegiatan mengumpulkan informasi tentang perkembangan atau pelaksanaan sebuah kegiatan. Pengawasan biasanya dilakukan secara berkala selama proses berlangsungnya kegiatan terkait. Sementara evaluasi adalah kegiatan menilai secara keseluruhan apakah sebuah kegiatan telah dilaksanakan sesuai dengan rencana atau kegiatan yang telah disusun sebelumnya. Evaluasi biasanya dilakukan pada akhir suatu kegiatan. 


\section{SIMPULAN}

Berdasarkan hasil analisis data yang telah dikemukakan sebelumnya, dapat diambil kesimpulan bahwa hasil analisis regresi linier sederhana menunjukkan bahwa secara parsial variabel pengelolaan dana desa berpengaruh terhadap peningkatan kesejahteraan masyarakat dengan taraf kepercayaan 95\%. Hal ini dilihat dari kesimpulan serupa juga diperoleh di mana hasil perolehan SPSS diperoleh $\mathbf{t}_{\text {hitung }}$ sebesar 8.995 dengan $\mathrm{p}$ value 0,000 . Berdasarkan ketentuannya jika $\mathrm{p}$ value $<$ dari 0,05 maka hipotesis alernatif ( $\mathrm{Ha}$ ) diterima, oleh karena $\mathrm{p}$ value $<0,05$ maka ini berarti variabel independen pengelolaan dana desa secara parsial berpengaruh positif signifikan terhadap variabel dependen kesejahteraan masyarakat.

Pemerintah diharapkan terus melanjutkan program dana desa untuk meningkatkan Kesejateraan dengan mngupayakan meningkatkan kualitas pendidikan, kesehatan melalui perbaikan sarana pendidikan dan kesehatan sehingga angka indeks pembangunan manusia dapat semakin meningkat dan mendorong pencapaian tujuan nasional yang mensejahterakan masyarakat. 


\section{PUSTAKA ACUAN}

Adi, Rianto. (2004). Metode Penelitian Sosial dan Hukum. Jakarta: Granit

Azuar Juliandi, Irfan. (2013). Metodelogi Penelitian Kuantitatif Untuk Ilmu-Ilmu Bisnis. Bandung: Citapusaka Media Perintis.

Badrudin, Rudy. (2012). Ekonomika Otonomi Daerah. Yogyakarta: UUP STIM YKPN

Basrowi, Suwandi. (2008). Memahami Penelitian Kualitatif. Jakarta: PT Rineka Cipta

Bungin,Burhan. (2009). Metodologi Penelitian Kuantitatif : Komunikasi, Ekonomi, Kebijakan Publik Serta Ilmu-Ilmu Sosial Lainnya. Jakarta: Kencana.

Danang Sunyoto. ( 2016). Metodologi Penelitian. Bandung: PT.Rafika.

Fahrudin, Adi. (2012). Pengantar Kesejahteraan Sosial. Bandung: Refika Aditama.

Ghozali, Imam. (2001). Aplikasi Analisis Multivariate dengan Progran SPSS. Semarang: Badan Penerbit Universitas Diponegoro.

Husein, Umar. (2002). Research Methods In Finanace and Banking. Jakarta : Gramedia Pustaka Utama.

Muhammad. (2008). Metodologi Penelitian Ekonomi Islam (pendekatanKuantitatif). Jakarta : Raja Grafindo Persada.

Pitri, Savarita. (2018). Analisis Manajemen Dana Desa Terhadap Pembangunan Desa Dalam Perspektif Ekonomi Islam. Skripsi Fakultas Ekonomi dan Bisnis Islam Universitas Islam Negeri Raden Intan. Lampung.

Rudy Syaf, Syurya Hidayat dan Erni Achmad. (2013). Faktor-faktor Yang Mempengaruhi Pendapatan Rumah Tangga Miskin Di Sekitar Taman Nasional Bukit Dua Belas (Studi Kasus Desa-Desa PenyangganTnbd Di Kecamatan Maro Sebo Ulu, Kabupaten Batang Hari). Jurnal Perspektif Pembiayaan dan Pembangunan Daerah, Vol.1, No.2.

Republik Indonesia. (2014). Undang-Undang No. 6 Tahun 2014 Tentang Desa. Jakarta

Republik Indonesia. (2016). Peraturan Menteri Desa, Pembangunan Daerah Tertinggal, dan Transmigrasi No. 22 Tentang Penetapan Prioritas Penggunaan Dana Desa Tahun 2017. Jakarta.

Rahardjo. (2010). Pengantar Sosiologi Pedesaandan Pertanian. Gadjah Mada University

Soekanto, Soerjono. (2006). Sosiologi Suatu Ilmu Pengantar. Jakarta: PT. Raja Grafindo Persada

Suharsimi Arikunto. (2006). Prosedur Penelitian Suatu pendekatan praktik. Jakarta : Rineka Cipta.

Sugiyono. (2011). Metode Penelitian Administrasi, Cet. Ke-19. Bandung: Alfabeta.

Soetomo. (2014). Kesejahteraan dan Upaya Mewujudkannya dalam Perspektif Masyarakat Lokal. Penerbit Pustaka Pelajar.

Todaro P Michael, Smith C Stphen. (2003). Pembangunan Ekonomi Di Dunia Ketiga, Edisi Indonesia. Jakarta: Penerbit Erlangga. 